\title{
Accounting Cooperative System of Business Vocational High School in Jakarta
}

\author{
Sri Zulaihati ${ }^{1}$, Santi Susanti ${ }^{1}$ \\ ${ }^{l}$ Economics Education Department, State University of Jakarta, Indonesia \\ sri.zulaihati@yahoo.com \\ ssusanti@unj.ac.id
}

\begin{abstract}
This research seeks to help the business continuity of the school cooperative, to solve the problem of cooperative sustainability as a learning center for students to improve the quality of education and relevance to the business world, access, efficiency and relevance of education to make higher competence of students in the senior high school level. Researchers see that school cooperatives have not been well managed because management resources do not maximize their potential, and the sustainability and development of school cooperatives tend to be stagnant, whereas the opportunity in order to maximize the cooperative's economic potential to improve the welfare of students is very wide open. School cooperatives also serve as laboratories for students to implement a dual system education is not optimal in its implementation, the involvement of students only to maintain the store, not to the stage of implementation of good management. This paper will explain how school cooperatives management in business vocational high school in Jakarta with qualitative research method.
\end{abstract}

Keywords: accounting system; cooperatives business; vocational high school

\section{Introduction}

School environment is one of the factors of student character building. Education can change the behavior of individuals to develop in a better decision. The form of character building not only in the process of learning in the class but also must provide knowledge and skills of students in social life and society. One of the factors that support the success of education is to successfully build, guide, and train students to have a physical character in leading an independent, creative, and responsible to themselves and to the community.

One of the educational institutions that aims to produce qualified human resources is vocational high school (SMK). Vocational schools as factors that can process inputs (students) into outputs (job candidates), where vocational high schools seek to create competent candidates in accordance with existing labor quality standards by conducting education programs in accordance with job demands. Oemar Hamalik (1991: 42) states that today the concept of national education leads to the preparation of ready-made and adaptive labor. Manpower graduates of formal and non formal education institutions must be ready to be placed in the field of work in accordance with the field of expertise and level of education. Student coaching services provided by schools in the field of student, one of them with the school cooperative. This field of student affairs can support in forming the character of students in performing skills in the field of business or work. Until the end of 2014 the number of active cooperatives in Jakarta is only $4 \%$ of the total active cooperatives in Indonesia. This is inversely proportional to the number of population densities in Jakarta up to 11,495 higher than in Indonesia. (Badan Pusat Statistik (BPS), 2016). This means that the population living in Jakarta, the participation rate in the cooperative is still very low, whereas the number of schools in Jakarta until 2014 there are 592, there is an imbalance in that the school cooperative has not been able to increase student participation in cooperative membership and cooperative management, After graduation they are not interested in 
becoming a cooperative member, whereas the cooperative contribution data to a country's economy is quite significant, as in Colombia, 8,124 cooperatives are responsible for $4.96 \%$ of GDP in 2009 . They employ over 137,888 people $-46 \%$ of which Men and women $54 \%$. And some sectors provide a significant proportion of $22.27 \%$ of all health sector jobs provided by cooperatives, $14.7 \%$ of employment in the transport sector, $7.7 \%$ in agriculture and $6.44 \%$ of jobs in the financial sector . Co-ops provide $91 \%$ of all microcredits in the country. (Source: CONFECOOP. Gestion paragraph construire una mejor opción de vida: Desempeno del Sector Cooperativo Colombiano 2009).

Student Cooperation according to Ali Imron (2004: 183) is a cooperative that is in the school environment but the management is done by students. Student Cooperation is a form of services provided by educational institutions to meet the needs of students. Student cooperative is one of the service program of educational management of learners. In order for school cooperatives to exist, it is necessary to include students in the management of student co-ops.

Cooperative school work program aims to lead to the fulfillment of the needs of all members of the school cooperative, to support that goal then the work program leads to the development of student character. This is to help develop imaginative, innovative and creative power for students, and can train students.

But the management of school cooperatives in SMK, not entirely submitted to the students who become the board, but all of them assisted by employees/staff appointed by the supervisor to assist in the management of cooperatives, given the co-operative counselors realize that students in addition to participate in the management of cooperatives, students Should be prioritized on the main subjects, namely in the academic field, so that students in providing services are not optimal, and students only play a role in managerial at break time, for that role of employees is needed in helping the managerial of cooperative activities in the school.

This research was conducted to find out how far the model of school work cooperative management program conducted by students who are expected to equip students graduates in organizational and entrepreneurship. The problem question is how "School Cooperatives Management in Business Vocational High School in Jakarta?"

\section{a. Cooperatives School}

\section{Review of Literature}

Cooperative is an organization that has been widely known by almost all levels of society, but in reality there are still many layers of society who have not fully understood the ins and outs of cooperatives (Ima Suwandi: 1986). Meanwhile, according to Law No.17 of 2012, the Cooperative is a legal entity established by an individual or a legal entity of the Cooperative, for the separation of its members' assets as business capital, which fulfills shared aspirations and needs in the economic, social and cultural fields in accordance with the values And cooperative principles.

While the school cooperative is a "cooperative established in a school environment whose members consist of school students". (http://www.sragenkab.go.id/berita/ berita.php?id=6992). According to Ima Suwandi (1986:2), "the school cooperative is a cooperative whose members consist of elementary school students, junior high school, upper secondary school, boarding school, and other equivalent educational institutions".

Thus it can be concluded that the school cooperative is a union that is in the school by selling the needs or purposes of teaching and learning with a relatively cheap price and 
managed by all citizens of the school. So the management of school cooperatives is an activity of arranging school cooperatives, among others, the process of planning, organizing, assessing all available resources within an organization by utilizing existing facilities to achieve the goals set.

\section{b. School Cooperative Goals}

The purpose of the school cooperative is to prosper its members. According to Ima Suwandi (1986: 3) some of the objectives of the school co-operatives are:

1. To support education conducted in the classroom with a variety of practical actions related to cooperative activities.

2. In the school cooperative practice is expected to meet the needs of each student's school equipment.

3. Avoid any conflict of interest among supervisors who are among them seeking to benefit from the cooperative school business activities.

4. To instill a sense of self-worth, to instill the same degree, and to cultivate the teachings of democracy and to arouse the attitude of courage to express the opinions of students who become members.

While other opinions say the purpose of the cooperative is:

1. Educate, instill and preserve a mutual living awareness and loyal friends among students

2. Growing the entrepreneurial spirit of students

3. Maintain and improve the quality of knowledge and skills in the field of cooperatives

4. To instill and nurture sense of responsibility and discipline in the life of mutual cooperation in society

5. Maintain good rapport and deep understanding between fellow members of the school cooperative

6. Instill self-esteem, equality and cultivate the spirit of democracy and raise the courage to express opinions

7. As a means to meet the needs of school tools

8. As a means of learning to apply economic principles in everyday life.

From the above opinion can be concluded the purpose of school cooperatives is to promote the welfare of members in particular and society in general, and participate in building the order of the national economy in order to realize a just and prosperous society. While the formation of school cooperatives among students implemented in order to support students' education and cooperative training / entrepreneurship. Thus, the purpose of its formation can not be separated from the purpose of education and government programs is to instill awareness of cooperative / entrepreneur from an early age.

According to Ajidedim (2008), in the research Developing Cooperative Business Concepts: Excavated From the Reality of Indonesian Society, This study aims to develop the core competencies and concepts of cooperative business according to the reality of cooperative business of Indonesian society based on people economy.

The research was conducted using qualitative methodology, ie Beyond Structuralism. Beyond Structuralism synergizes synchronous (contextual) and postructuralist anthropology (past). The methodology is run by Pierre Bourdieu's Constructivist Structuralism method to know empirically (habitus, capital, field and practice) of cooperative business activities in Indonesia. 
Another study by Tal Gilead (2009) entitled Human Capital, Education and the Promotion of Social Cooperation: A Philosophical Critique in the journal Springer Science, Business Media B.V. 2009, Human capital has played a leading role in guiding educational policy, the philosophical issues stemming from this development are rarely discussed. In this article, critics examine how the idea that human capital should serve as a guide for the establishment of educational policy stands in relation to the role assigned to education in promoting cooperatives aimed at social.

\section{Research Method}

The study population is all of the School Cooperatives in SMK in Jakarta. The sample of the research is 40 School Cooperatives in SMK that exist in Jakarta. Sources of data used are primary data that is data taken directly from the respondents using questionnaires and interviews about the Cooperative School Management. And secondary data is data obtained indirectly from the source, in the form of data obtained from SMK in Jakarta.

This research is a qualitative descriptive research. The object studied in this research is the management of cooperative work program of school in Vocational High School Cooperative in Jakarta. The subjects of this research are principal, cooperative teacher teacher, employee, and student as well as board and member of school cooperative. The data obtained comes from interviews, observations, and scrutiny of documents.

\section{Discussion}

In accordance with the decree issued by the Minister of Trade and Cooperatives and the Minister of Education and Culture No. 719 / Kpb / XII / 79 and No. 282a / P / 1979 on the establishment of cooperatives of schools, universities and educational institutions within the department of education and culture and with the vision and Mission made by the school. The school cooperative is one of the substances in the management of special school services whose existence greatly supports student learning activities in schools. The purpose of establishing this school co-operative is to educate and instill awareness of working life together, work together and foster a sense of loyalty among students, and assist in developing and enhancing the knowledge and skills of students in cooperating. School cooperatives are established in accordance with the principles of cooperatives on the basis of and by members and are carried out for the benefit of members together.

The school cooperative serves and provides the items that all the school and residents of the school environment need. The goods provided in the school cooperative are not only goods or school equipment but also provide goods for daily needs.

Data on the management of cooperative school work programs in SMK in Jakarta include planning, implementation, evaluation and obstacles faced in managing school cooperative work program obtained from the interview. Data obtained from the results of documentation and observation by researchers used to support and complete the results of analysis of the data obtained from the interview. The following will present the research that will be used to answer the problem question.

\section{School Cooperative management}

a. Organization and Business Sector Management 
In the field of school cooperative organization, of all the vocational schools that are the place of cooperative observation in schools is only savings and loan cooperatives whose members are teachers and employees of the school. Each school has a business unit that provides ATK and daily necessities from school residents whose form of business is not a cooperative. The business units that exist in each school's capital come from the rest of the school's activities or help from government activities. In fact, there are 3 SMKs that work together with well-known retail stores, with non-binding agreements, the retail only provides goods, but management is handed over completely to the school. The existing business units in each school have the opportunity to develop into a cooperative school by involving students as members of the cooperative and play an active role as a board. This is the management development undertaken:

- Improve the welfare of employees in the school cooperative, so that the sense of responsibility and sense of belonging to the higher and can serve the members with the very satisfying.

- Maintain the achievements that have been obtained by improving and implementing cooperative education well to the board.

- Increase business by cooperating with other parties

b. Administration Management

In the field of cooperative administration and business units that exist in schools, efforts to fix the administration by improving administrative workmanship and documents / archive cooperatives are still manual and use a simple spreadsheet program. In addition, cooperatives and business units prepare and add books for help for the smooth administration process.

\section{c. Human Resources Management}

The human resources management in an effort to improve and develop the spirit of cooperatives for members, by activating cooperative daily program, although for students this is still limited because the students are still not biased to be members of the cooperative.

Including members in every forum of cooperative activities both internally and externally, it is limited to teachers and employees, not for students. Obstacles in the development of cooperative schools by involving students as members of the cooperative:

1. Schools do not want to burden students with the affairs outside school, but this can be resolved by making the school cooperative as an extra-curricular organization.

2. Schools have not dared to burden students by collecting compulsory or basic dues, as a condition of becoming a member of the cooperative. Should have been socialized since the beginning that the membership of the cooperative is voluntary.

\section{Conclusion}

Based on the above discussion, it can be concluded that the management of school cooperative work programs in SMK in Jakarta which includes planning, implementation, evaluation, constraints and solutions during the management are as follows:

1. Cooperatives management of vocational school in Jakarta, still need improvement especially in principal of cooperation which is voluntary from the members. 
2. Obstacles encountered in the management of school cooperative work programs most of the factors derived from human resources. These obstacles include the lack of interest of students in the external activities of the school cooperative, the lack of responsibility and the limitations of the board in making the report, the lack of responsibility of the board in the task of being operated.

3. Solutions to these barriers are done by approaching the board, providing training, improving cooperation in cooperatives and coordinating with all administrators and employees of the cooperative regarding the process of running cooperative activities with the aim that school cooperative work programs can be achieved.

\section{References}

[1] Alwert, K.; Bornemann, M.; Will, M. (2008) Wissensbilanz - Made in Germany. Leitfaden 2.0 zur Erstellung einer Wissensbilanz, Guideline Published by the Federal Ministry for Economics and Technology, Berlin,

[2] Alwert, K.; Vorsatz, N. (2005) „Intellektuelles Kapital in deutschen Unternehmen aktuelle Studie des Fraunhofer IPK”, Wissensbilanzen. Intellektuelles Kapital erfolgreich nutzen und entwickeln, Berlin, Springer, pp. 323 - 335.

[3] Becker, G. S. (1964) Human Capital; Chicago, University of Cicago Press.

[4] Botosan, C. A.; Plumlee, M. A. (2000) "Disclosure Level and Expected Cost of Equity Capital: An Examination of Analysts' Rankings of Corporate Disclosure and Alternative Methods of Estimating Expected Cost of Equity Capital", [online]

[5] Dekopin. 2006. Program Aksi Dekopin. Jakarta.

[6] Del Bello, A. (2003) "Credit Rating and Intangible Assets: Some Observations on Current Practices", http://www.euintangibles.net/library/localfiles/WP4/4.7DelBello2003.pdf

[7] Edvinsson, L.; Malone, M. (1997) Intellectual Capital; New York, Harper Business.

[8] European Commission (2008) InCaS: Intellectual Capital Statement - Made in Europe. European ICS Guideline, [online] www.incas-europe.org

[9] European Foundation for Quality Management EFQM (2003) "EFQM Excellence Model"; [online] http://www.efqm.org/Default.aspx?tabid=35.

[10] Financial Accounting Standards Board (2001) FAS 142 "Goodwill and Other Intangible Assets", FAS 141: "Business Combinations", Norwalk, Connecticut, [online] http://www.fasb.org/pdf/fas142.pdf, http://www.fasb.org/pdf/fas141.pdf.

[11] Fitz-enz, J. (1984) How to measure human resources management; New York, McGraw-Hill.

[12] Flamholtz, E. (1974) Human Resource Accounting; Encino, Dickenson.

[13] Gilead, Tal (2009) yang berjudul Human Capital, Education and the Promotion of Social Cooperation: A Philosophical Critique

[14] http://ajidedim.wordpress.com/2008/01/20/mengembangkan-konsep-bisnis-koperasidigali-dari-realitas-masyarakat-indonesia/

[15] http://ayucintyavirayasti.blogspot.com/2011/11/mengapa-koperasi-di-indonesia-sulit.html

[16] http://dwiermayanti.wordpress.com/2011/05/31/akuntansi-sumber-daya-manusia/

[17] http://id.shvoong.com/business-management/accounting/2167118-akuntansi-sumberdaya-manusia/

[18] http://papers.ssrn.com/sol3/papers.cfm?abstractid=224385\#PaperDownload. 
[19] Ismangil, W. Priono. 2006. Menumbuhkan Kewirausahaan Koperasi Melalui Pengembangan Unit Usaha yang Fleksibel dan Independen. Infokop. 29-XXII. Hal 72-76.

[20] Jauhari, Hasan. 2006. Mewujudkan 70.000 Koperasi Berkualitas. Infokop. No 28-XXII. Hal.1-9.

[21] Mertins, K.; Alwert, K.; Will, M. (2006) "Measuring Intellectual Capital in European SME", Proceedings of I-KNOW'06, 6th International Conference on Knowledge Management, published by Tochtermann, K.; Maurer, H., Graz, Austria, pp 21-25.

[22] Mertins, K.; Wang, W.-H.; Will, M. (2007) "How to ensure the quality and credibility of Intellectual Capital Statements", Proceedings of the 8th European Conference on Knowledge Management, Barcelona, Spain.

[23] Mertins, K.; Will, M. (2008) "Strategic Relevance of Intellectual Capital in European SMEs and Sectoral Differences. InCaS: Intellectual Capital Statement - Made in Europe", Proceedings of the 8th European Conference on Knowledge Management, Barcelona, Spain.

[24] Mertins, Kai, et.al. (2008) Intellectual Capital Statement. Measuring Intellectual Capital in European Small- and Medium sized Enterprises, IPK, Berlin, Germany.

[25] Mørck, F., Hall, M. and Vali, E. (2003) Banking and Venture Capital Metrics”, [online]

[26] Sularso. 2006. Membangun Koperasi Berkualitas: Pendekatan Substansial. Infokop Nomor 28-XXII. Hal 10-18.

[27] Suwandi, Ima. 1982. "Seluk Liku Koperasi Madrasah dan Koperasi Pondok

[28] UU. No. 17 Tahun 2012 tentang perkoperasian

[29] www.bps.go.id 